\title{
"THE RIME OF THE ANCIENT MARINER" BY S.-T.COLERIDGE IN RUSSIAN TRANSLATIONS
}

\author{
Dmitry N. Zhatkin ${ }^{1}$, Anna A. Ryabova ${ }^{1}$ \\ ${ }^{1}$ Department of Translation and Methods of Translation, Penza State Technological University, Penza, \\ Russian Federation \\ Correspondence: Zhatkin Dmitry Nikolayevich, Department of Translation and Methods of Translation, \\ Penza State Technological University, Baidukov Thoroughfare / Gagarin Street, 1a / 11, Penza, Russian \\ Federation
}

\begin{abstract}
The article provides a comparative analysis of Russian translations of S.-T.Coleridge's poem "The Rime of the Ancient Mariner" (1797 - 1798) made in the second half of the XIXth - at the beginning of the XXth century by F.B.Miller (1854), N.L.Pushkarev (1878), A.A.Korinfsky (1893) and N.S.Gumilev (1919). It finds distinctive features of translators' creative manners. Methodologically, the article relies on Alexander N.Veselovsky, V.M.Zhirmunsky, M.P.Alekseyev, Yu.D.Levin's fundamental works, what allows to reveal characteristics of poetics of translations, to disclose features of their national originality, to understand specifics of the description of the lyrical character, etc. Yu.M.Lotman, E.I.Klimenko, G.G.Podolskaya's research approaches, provisions of M.M.Bakhtin's theory about dialogue and "foreign word" were taken into account. In the course of the research cultural and historical, historical and genetic, historical and typological approaches, and also methods of a problem, complex, comparative analysis were used. According to art expressiveness, Russian translations of "The Rime of the Ancient Mariner" made in the second half of the XIXth century are worse than the English original. For example, in F.B.Miller's translation there are deviations in the creation of the bride's image in the wedding scene, the episode, describing the perception of the ship by the monk-hermit, is unfairly laconically presented; in N.L.Pushkarev's translation, abounding with comparisons, an excessive attention is paid to the Ancient Mariner's image with his characteristic magnetic, fiery eyes; in A.A.Korinfsky's translation descriptions of sufferings of the Ancient Mariner and his team underwent considerable changes, and the ballad description by means of the prevailing use of the corresponding lexicon was turned into Gothic one. The translation of "The Rime of the Ancient Mariner" made by N.S.Gumilev is almost faultless: the Russian poet precisely adhered to the "nine precepts of the translator" established by him, observing the number of verses, and metre, and rhymes, and character of the vocabulary, and sense of the original; besides, N.S.Gumilev kept all repetitions used by S.-T.Coleridge to give the importance and dramatic nature to the narration. In spite of every Russian translator's own reasons for addressing to S.-T.Coleridge's work (starting with the declaration of the need to atone his sin by suffering, and finishing with the aspiration to show infinity of the worlds - both external and internal) all Russian interpretations have some rejection of significantly amplified individualistic tendencies, leading a person to self-isolation and internal loneliness.
\end{abstract}

Keywords: poetic translation, international literary connections, comparative study, reminiscence, tradition, intercultural communication, artistic detail

\section{INTRODUCTION}

"The Rime of the Ancient Mariner" written by S.-T.Coleridge in November, 1797 - March, 1798 specially for the collection "Lyrical Ballads" (1798) made of W.Wordsworth and S.-T.Coleridge's verses can be considered to be one of the best poetic works created in different years by outstanding English poets representatives of the "Lake School". While creating his work, Coleridge intentionally imitated the style of authors of medieval folk songs familiar to him due to the popular collection by Thomas Percy "Reliques of Ancient English Poetry" (1765). From here the poet borrowed the so called "ballad size" - four and three metre lines rhymed according to the scheme abcb, and sometimes abcbdb, and a special melodic intonation of a verse. Except the collection by Th.Percy Coleridge knew collections written under the influence of this collection - "William and Helen's Prosecutions" (1796) of W.Scott and "Lenora" (1775) of the German poet G.A.Burger written earlier and already translated into English by then. In the preface to the first edition of "Lyrical ballads" it was reported, that the "Ancient Mariner" had been created in imitation of the "style and 
spirit of ancient poets". Respectively, the action of the poem took place in the XVth - XVIth centuries, when, according to Coleridge's contemporaries, folk songs were composed and written down. "The Rime of the Ancient Mariner" reflects the spirit of the medieval ballad, what is proved by the fact that the old man killed an albatross with an arrow from an arbalest ("With my cross-bow / I shot the Albatross"). The atmosphere of the Middle Ages is transferred by means of characteristic pleonasms ("The Wedding-Guest he beat his breast", "fear not, fear not, thou Wedding-Guest", "I tell to thee, thou Wedding-Guest", "be calm, thou Wedding-Guest") and a large number of archaisms ("spake", "loon", "eftsoons", "bassoon", "uprist", "wist", "countree", "anear", "shrive", "afeard", etc.). Also Coleridge originally stylized the spelling of the name of the poem - "The Rime of the Ancyent Marinere" in the style of "ancient poets". However, in the subsequent edition of "Lyrical ballads" (1800) the spelling was modernized. In the second edition of the poem Coleridge reduced the number of archaisms, reduced more than forty lines and added several new. In the edition of "Lyrical ballads" (1802) the short summary of contents (Argument) was omitted. In the collection "Sibylline Leaves" (1817) Coleridge included glosses in the text of the poem; he stylized them in imitation of prose of the beginning of the XVIIth century, reduced nine lines and added eighteen new. The English poet made some more minor changes in the final version of 1834.

\section{LITERATURE REVIEW}

S.-T.Coleridge told about the history of the creation of the poem "The Rime of the Ancient Mariner" in 1817 in chapter XIV of "Biographia Literaria": "During the first year that Mr. Wordsworth and I were neighbours <1796>, our conversations turned frequently on the two cardinal points of poetry, the power of exciting the sympathy of the reader by a faithful adherence to the truth of nature, and the power of giving the interest of novelty by the modifying colours of imagination. The sudden charm, which accidents of light and shade, which moonlight or sun-set diffused over a known and familiar landscape, appeared to represent the practicability of combining both. These are the poetry of nature. The thought suggested itself (to which of us I do not recollect) that a series of poems might be composed of two sorts. In the one, the incidents and agents were to be, in part at least, supernatural; and the excellence aimed at was to consist in the interesting of the affections by the dramatic truth of such emotions as would naturally accompany such situations, supposing them real. And real in this sense they have been to every human being who, from whatever source of delusion, has at any time believed himself under supernatural agency. For the second class, subjects were to be chosen from ordinary life; the characters and incidents were to be such, as will be found in every village and its vicinity, where there is a meditative and feeling mind to seek after them, or to notice them, when they present themselves. In this idea originated the plan of the "Lyrical Ballads": in which it was agreed, that my endeavors should be directed to persons and characters supernatural, or at least romantic, yet so as to transfer from our inward nature a human interest and a semblance of truth sufficient to procure for these shadows of imagination that willing suspension of disbelief for the moment, which constitutes poetic faith. <..> With this view I wrote the "Ancient Mariner" [1].

W.Wordsworth's detailed memoirs about the memorable event in the life of the "Lake School" are preserved: "In the autumn of 1797, Mr. Coleridge, my sister, and myself started from Alfoxden pretty late in the afternoon, with a view to visit Linton, and the Valley of Stones near to it; and as our united funds were very small, we agreed to defray the expense of the tour by writing a poem $\langle\ldots\rangle$. In the course of this walk was planned the poem of the "Ancient Mariner", founded on a dream, as Mr. Coleridge said, of his friend Mr. Cruikshank <Cruickshank told Coleridge that he had dreamt a ghost ship, onboard which some figures had been moving>. Much the greatest part of the story was Mr. Coleridge's invention; but certain parts I suggested; for example, some crime was to be committed which was to bring upon the Old Navigator, $<\ldots>$, the spectral persecution, as a consequence of that crime and his own wanderings. I had been reading in Shelvocke's "Voyages" <"A Voyage Round the World by Way of the Great South Sea" (London, 1728)>, a day or two before, that, while doubling Cape Horn they frequently saw albatrosses in that latitude, the largest sort of sea-fowl, some extending their wings twelve or thirteen feet, 'Suppose,' said I, 'you represent him as having killed one of these birds on entering the South Sea, and that the tutelary spirits of these regions take upon them to avenge the crime. The incident was thought fit for the purpose, and adopted accordingly. I also suggested the navigation of the ship by the dead man, but do not recollect that I had anything more to do with the scheme of the poem. We began the composition together, on that to me memorable evening, I furnished two or three lines at the beginning of the poem, in particular - "And listens like a three years' child / The Mariner hath his will" < the lines "And thou art long, and lank, and brown, / As is the ribbed sea-sand" 
were also composed by Wordsworth>. As we endeavoured to proceed conjointly our respective manners proved so widely different, that it would have been quite presumptuous in me to do anything but separate from an undertaking upon which I could only have been a clog" [2].

In the fragment from the book by George Shelvocke, which was remembered by Wordsworth during the walk with Coleridge, a picturesque description of Antarctica is presented and a symbolical image of an albatross is created: "the heavens were perpetually hidden from us by gloomy, dismal clouds. $<\ldots>$ There was no sign of life; no fish to be seen - nor one sea-bird; except a disconsolate black Albatross, who accompanied us for several days, hovering about us as if he had lost himself, till Hatley, (my second Captain) observing, in one of his melancholy fits, that this bird was always hovering near us, imagin'd, from his colour, that it might be some ill omen. That which, I suppose, induced him the more to encourage his superstition, was the continued series of contrary tempestuous winds, which had oppress'd us ever since we got into this sea. But be that as it would, he, after some fruitless attempts, at length, shot the Albatross, not doubting (perhaps) that we should have a fair wind after it" [3, p. 47]. Most likely, Coleridge was familiar with this book, though, according to Wordsworth, he had the idea to shoot an albatross, which appeared after reading of the work of G.Shelvocke [4, p. 185]. Anyway, the basis of Coleridge's poem was formed by the story based on a prejudice of seamen, for whom a black albatross was the same fatal messenger as well as the Flying Dutchman.

\section{MATERIALS AND METHODS}

The methodology of the work is based on achievements of Russian literary science and criticism of the XIXth - XXth centuries, modern Russian and foreign literary criticism. Scientific approaches of representatives of the Leningrad comparative-historical school (M.P.Alekseyev, Yu.D.Levin, V.E.Bagno, R.Yu.Danilevsky, P.R.Zaborov, D.M.Sharypkin, etc.) are used. They found plurality of influences of a foreign language culture on Russian literature, developing in close connection with European literatures. This research essentially relies on fundamental works of Alexander N.Veselovsky and V.M.Zhirmunsky, what allows to reveal characteristics of poetics of works, to disclose features of their national originality, to understand specifics of the description of the lyrical character, etc. Research approaches of Yu.M.Lotman, E.I.Klimenko, G.G.Podolskaya, provisions of M.M.Bakhtin's theory about dialogue and "foreign word" were taken into consideration. In the course of studying cultural and historical, historical and genetic, historical and typological approaches, and also elements of a social and psychological method, while reconstructing separate biographic realities, that was quite often necessary for the objective perception of the literary text, were naturally used. While presenting a developed literary interpretation of literary texts caused by the theme of the work, methods of a problem, complex, comparative analysis were used.

\section{RESULTS}

The travel of the Ancient Mariner took place about 1500, after the discovery of America by Columbus, but before Magellan in 1522 went round the Cape Horn, having gone from the Atlantic Ocean to the Pacific one. It is possible to understand from the text of the poem, that the ship of the Ancient Mariner went round the Cape Horn: if at the beginning of the travel the sun rises on the left: "The Sun came up upon the left, / Out of the sea came he!" <here and in many other episodes of the "Ancient Mariner" the poet personified the sun, thereby following traditions of medieval poetry> [5, p. 46] - "Here on the left the sun from a wave, / Flaring, rises" (F.B.Miller's translation) [6, p. 213], after the murder of the albatross it already rises on the right: "The Sun now rose upon the right: / Out of the sea came he" [5, p. 52] - "Here the sun on the right side / From the sea rises" (F.B.Miller's translation) [6, p. 214]. N.L.Pushkarev complemented his translation with the description of the sun: "...The fiery circle of the sun / Came up on the left from waves stately" [7, p. 11]; "The sun again, but now on the other side, / As if full of grief and anger, / Hiding in gray fog, rose from a wave" [7, p. 12]. A.A.Korinfsky in his translation initially did not give any particular importance to this fact: "From sea waves the star of day / Ascended over us now" [8, p. 2], however, subsequently he recreated the original plan precisely: "Out of water comes the sun, / On the right the way for us lighting" [8, p. 3]. In this N.S.Gumilev's translation was significantly more successful: "Here the sun on the left from a wave / Ascends in height" [5, p. 439] and "Here the sun on the right from a wave / Ascends in height" [5, p. 441]. And N.S.Gumilev not only precisely conveys the meaning, but also observes the repetition important for Coleridge. In these lines it is possible to see a reminiscence from Herodotus, who wrote the words of Phoenician seamen, that, when they had been sailing in the southern seas, the sun had risen on the right, but not on the left. The same lines confirm also, that the travel took place prior to Magellan's expedition: "We 
were the first that ever burst / Into that silent sea" [5, p. 54] - "It <the ship> was here the first to rush in these waves, / In this sea known only to God..." (N.L.Pushkarev's translation) [7, p.12]; "... waters, / Which were not sailed / By seamen in former years" (A.A.Korinfsky's translation) [8, p. 4]; "We were the first to enter the vast expanse / Of those silent waters" (N.S.Gumilev's translation) [5, p. 442]. In F.B.Miller's translation there is some doubt, that seamen were pioneers: "Before us probably there was / Nobody in those waters" [6, p. 214].

The action of the poem takes place in Catholic England, what is proved by the hero's prayers impossible for Protestants, turned to the Virgin and Saints, for example: "Heaven's Mother send us grace!" [5, p. 62], "To Mary Queen the praise be given!" [5, p. 74], "Suie my kind saint took pity on me" [5, p. 74]; compare in N.S.Gumilev's translation: "Hear, Maria, us!" [5, p. 446], "To Maria eternal praise!" [5, p. 451], "My Saint regretted me" [5, p. 451]. In the work by Coleridge there is also a figure of the Catholic monk-hermit, absolving the Ancient Mariner's sins. At the same time the glosses stylized in imitation of the XVIIth century prose, which nobody of Coleridge's literary predecessors had, create some double prospect, that emphasizes all complexity and ambiguity of the action.

The motive of a wandering has great literary history. It is present in Homer's "Odyssey", where the hero, as the Ancient Mariner, also survived all his companions and then wandered alone before returning home. During the Christian era this motive found some new sense of a pilgrimage, terrestrial wandering of a soul. In this way it was apprehended by famous predecessors of Coleridge - Geoffrey Chaucer ("The Romaunt of the Rose") and John Bunyan ("The Pilgrim's Progress from This World to That Which Is to Come"). But in the poem by Coleridge the characteristic understanding of a wandering intertwines with many plans, occupying its author at that time, in particular, with the ideas of the creation of the epic about origin of the evil after the manner of J.Milton and writing anthems to the sun, moon and elements, for what the material, as Coleridge's notebooks show, was actively gathered at that time.

A terrifying story of the character of the ballad, who threw out a challenge to nature, having awakened mysterious forces, which revenged him for his crime against the world of harmony and true beauty, was as if projected on a poetic outline of the anthem to elements. All considerations of the poet about the conflict of belief and reason, God and nature, mechanistic and transcendental understanding of the world, about mysteries of life and pangs of conscience in an allegoric form found the place in the text of the poem, as if having created two layers of the narration - "geographical", telling about the Ancient Mariner's sailing from the Atlantic Ocean to the Pacific one, and symbolic and fantastic, describing revenge of otherworldly forces for the murder of the albatross. The fact that Coleridge wrote the "Ancient Mariner" prior to his travel by sea to Germany and Malta, is surprising. In spite of the fact that the poet did not know the sea, the extraordinary force of imagination helped him to create "a majestic, incomparable picture of the icy ocean with huge floating ice floes, dismally shining with emerald green gloss in the moonlight, a picture of the roaring snow hurricane, bending masts with groaning roar and crackling blocks, at last, colourful pictures of the tropics and equator, presenting which $\langle\ldots\rangle$ the poet surpassed not only people, but also the very nature" [4, p. 186]. The "Ancient Mariner" not only "opens new maritime routes", but also makes "a wandering in unknown depths of a soul" [5, p. 26-27]. Exactly due to an organic combination of real and fantastic images the poem produces an extremely strong impression.

Comparing the poet's notebooks with the text of the "Ancient Mariner", J.L.Lowes found a huge number of sources, which Coleridge referred to in his work, - from the Bible to "Scientific Notes of the London Royal Society": from the last his image of the "horned moon" is borrowed ("The horned Moon, with one bright star / Within the nether tip") - at that time the London Royal Society actively discussed a strange nature phenomenon - the appearance of the light, similar to a star, in the dark part of the Moon on March 7, 1794 [9, p. 34 - 36]. It is quite possible that the subject line was partly borrowed by Coleridge from W.Shakespeare's "Macbeth", where "the old witch goes under a sail, on a sieve, to Aleppo to vent her terrible anger on one sailor there. She decided to drive his ship the devil knows where, to take his dream away forever, and, having dried him up like hay, to free him wherever he wishes with a stamp of the "damned person"; from there ghosts as passengers, awful "Nightmare" and the image of "Death" could have been taken: "Demons $<\ldots>$ were here earlier, but only Coleridge with his hand created human images from them" [4, p. 184]. 
In the structure of the poem the combination of a poetic gift of Coleridge and his tendency to logic and philosophical generalization received some reflection: on the one hand, the "Ancient Mariner" is constructed according to the accurate plan and reveals a clearly formulated thought, on the other hand, it consists of separate images, which are beyond rational thinking. In the Latin epigraph, taken from the composition of the English prose writer Thomas Burnet "Archaeologiae Phylosophicae sive Doctrina Antiqua De Rerum Originibus" and preceding the "Ancient Mariner" in the collection "Sibylline Leaves" (1817), a great number of beings, with which the world surrounding us is full, was indicated - it was done to encourage the minds, who got used to ordinary daily occurrence, to think: "I readily believe that there are more invisible than visible Natures in the universe. But who will explain for us the family of all these beings, and the ranks and relations and distinguishing features and functions of each? What do they do? What places do they inhabit? The human mind has always sought the knowledge of these things, but never attained it. Meanwhile I do not deny that it is helpful sometimes to contemplate in the mind, as on a tablet, the image of a greater and better world, lest the intellect, habituated to the petty things of daily life, narrow itself and sink wholly into trivial thoughts. But at the same time we must be watchful for the truth and keep a sense of proportion, so that we may distinguish the certain from the uncertain, day from night" [5, p. 475]. In Burnet Coleridge found the exact definition of his creative mission, consisting in the recognition of the need of emphasis of invisible properties, which had never been comprehended by the mind of a person before, in the realization of "supernatural life", while preserving the "poetic truth" [10, p. 68]. Among Russian translators of the XIXth century only A.A.Korinfsky paid attention to the epigraph.

The "summary", preceding the poetic text, in many respects assumed an adventure character of the story, however, from the very beginning not the action, but rather the general drama background of the narration and a demonic image of the Ancient Mariner thrilled. The external story was step by step developed in the prosaic narration (glosses). Unfortunately, none of the Russian translators of this poem in the XIXth century - neither F.B.Miller, nor N.L.Pushkarev, nor A.A.Korinfsky translated the glosses and summary important for understanding of this poem. In N.S.Gumilev's translation ("The Poem of the Old Seaman", 1919) there are glosses. Nearby, in poetic stanzas, there is a drama action with two heroes. The image of the gloomy Ancient Mariner with a fiery look contrasts with the image of the young Wedding Guest, striving for joyful fun. In the first part the Ancient Mariner's story is interrupted by the Wedding Guest thrice, but after the Mariner speaks about his crime the young man becomes silent - no remark interrupts the Ancient Mariner's story in the second and third parts of the narration. A new remark of the young man follows only the Mariner's story about the death of two hundred crew members. At last, the Wedding Guest gives the last shy exclamation in the middle of the fifth part, then till the final of the poem he is not heard any more. At the same time, the internal dramatic nature of the Ancient Mariner's monologue increases, Coleridge introduces the dialogue of spirits at the end of the fifth - the beginning of the sixth part, then presents the conversation of the Fisherman and Hermit.

The ship of the Ancient Mariner quietly crosses the equator, but then the storm carries the vessel away to the South Pole, to the country of ices, from where, apparently, there is no rescue; however, the albatross, who appeared unexpectedly, helps the ship to leave the kingdom of ices. In glosses the albatross is called "a bird of good omen", "the pious bird of good omen", "the bird of good luck". According to some scientists, the albatross personifies beneficial powers of nature, "uniform life" mentioned in "Aeolian Harp"; others see Jesus Christ in this bird [11, p. 85]. But, most likely, the albatross is important for Coleridge as the reason of that penalty, which his murder involves. The murder of the albatross by the Ancient Mariner is committed unexpectedly, not motivated. This evil does not have any reasonable explanation, and, consequently, is the result of the original sin which led to the damage of the human nature. Coleridge wrote about it to his brother in March, 1798, when the first version of the poem had just been finished: "I believe most steadfastly in original Sin; that from our mothers' wombs our understandings are darkened"; and even where our understandings are in the Light, that our organization is depraved; and our volitions imperfect" [12, p. 396]. In spite of the fact that in verses Coleridge does not give any estimates to the albatross ("The Albatross did follow"), Miller, and Pushkarev, and Korinfsky, referring to glosses, while translating, characterized the bird as a good omen: "The albatross flew to us... / It brought happiness to us" (F.B.Miller's translation) [6, p. 214]; "...The albatross began to whirl... / He flew from an ice spur, as if an angel descended from the sky, / All recognized the messenger of God in it" (N.L.Pushkarev's translation) [7, p. 12]; "The white albatross is whirling / And beating air with his wings... / Oh, it was a good sign - / The herald of the end of the way" 
(A.A.Korinfsky's translation) [8, p. 3]. Gumilev has glosses, and, therefore, in his translation here he is true to the original again.

Having murdered the albatross, the Ancient Mariner joins the evil and is alone against the world of nature, hostile to him now. At first superstitious sailors condemn the Ancient Mariner for committing "a hellish thing", but then praise, also joining his crime: "For all averred I had killed the bird / That made the breeze to blow. / Ah wretch! said they, the bird to slay, / That made the breeze to blow! / < . . / Then all averred, I had killed the bird / That brought the fog and mist. / 'Twas right, said they, such birds to slay, / That bring the fog and mist" [5, p. 52 - 54]; compare: "They reproached me: "You killed / That, who was glad to see us, / Who sent us wind!" / $<\ldots>/<\ldots>$ and everyone said: / "You are right, that punished / That, who was dangerous for us, / Who sent us fog" (F.B.Miller's translation) [6, p. 214].

As a result the ship stops on the equator "in a strip of dead calm <Coleridge showed the whole deplorableness of the situation by the comparison borrowed from Spencer - "'Twas sad as sad could be", when because of intolerable heat boards on the deck started "shrinking", when fetid green mold appeared in tubs, when at noon in the "copper sky" the "bloody sun", as the heated horn, breathed burning fire, when because of intolerable thirst they began to rattle as if their throats were filled with "soot", and flicked out their tongues as if wanted to lick their "black lips baked"; when at night they groaned and raved about some polar ghost, which had driven them here from "the land of mist and snow" and "plagues" them now, sitting at the nine fathom depth; when the very sea began "rotting", and some "slimy things" appeared in it; when at night the "death-fires" "danced" in the crowd around the ship, and water burned as the "witch's oils", green, blue, and white" [4, p. 188]. This terrible picture reproduces the state of the hero's soul, embodying the feeling of his fault and internal loneliness: "All in a hot and copper sky / The bloody sun, at noon, / Right up above the mast did stand, / No bigger than the Moon. / Day after day, day after day, / We stuck, nor breath nor motion; / As idle as a painted ship / Upon a painted ocean. / Water, water, everywhere, / And all the boards did shrink; / Water, water, everywhere, / Nor any drop to drink. / The very deep did rot: O Christ! / That ever this should be! / Yea, slimy things did crawl with legs / Upon the slimy sea. / About, about, in real and rout / The death-fires danced at night; / The water like a witch's oils, / Burnt green, and blue and white. / And some in dreams assured were / Of the Spirit that plagued us so; / Nine fathom deep he had followed us / From the land of mist and snow. / And every tongue, through utter drought, / Was withered at the root; / We could not speak, no more than if / We had been choked with soot" [5, p. 54-58].

While describing the heated sky Coleridge used his own memories of an awful heat in England in 1783. In this regard J.L.Lowes quotes the following lines of the English naturalist Gilbert White, who described the summer of 1783 like this: "The summer of the year 1783 was an amazing and portentous one, and full of horrible phaenomena; for $\langle\ldots\rangle$ the peculiar haze, or smokey fog, that prevailed for many weeks in this island, $\langle\ldots\rangle$, was a most extraordinary appearance, unlike anything known within the memory of man. $\langle\ldots\rangle$ The sun, at noon, looked as blank as a clouded moon, and shed a rust-coloured ferruginous light on the ground, and floors of rooms; but was particularly lurid and blood-coloured at rising and setting. All the time the heat was so intense" [9, p. 145 - 146]. Coleridge borrowed the description of fish-slugs from the book by the German seafarer F.Martens "A Voyage to Spitzbergen" (1694).

J.L.Lowes gives the following fragment from the book by Captain James Cook "A Voyage to the Pacific Ocean in 1776 - 1780" (1784) for comparison to the quoted fragment, it has the reference in Coleridge's notebooks: "During a calm $<\ldots>$ some parts of the sea seemed covered with a kind of slime; and some small sea animals were swimming about $\langle\ldots>$ that had a white, or shining appearance. $<\ldots>$ When they began to swim about, which they did, with equal ease, upon their back, sides, or belly, they emitted the brightest colours of the most precious gems. $\langle\ldots>$ Sometimes they $<\ldots>$ assumed various tints of blue. $<\ldots>$ But $\langle\ldots\rangle$ the colour was, chiefly, a beautiful, pale green, tinged with a burnished gloss; and, in the dark it had a faint appearance of glowing fire" [9, p. 75]. In this fragment it is possible to see a tradition of the witches' round dance from "Macbeth" by Shakespeare. Coleridge also read about shining and as if burning sea water in the book by Joseph Priestley "Optics: The History and Present State of Vision, Light, and Colours" (1772) in the chapter about luminescence of decaying bodies. These influences are distinctly shown not only in the fragment given above, but also in the further text of the "Ancient Mariner". 
N.S.Gumilev is most original in interpretation of the given fragment from the work by S.-T.Coleridge: "In the hot, copper heaven / At midday / Over the mast there is the Sun, as blood, / About the Moon size. / Days after days, days after days / We wait, our ship sleeps, / As in the drawn water, / Drawn stands. / Water, water, only water. / But the tub lies upside down; / Water, water, only water, / We drink nothing. / How smells of rot - oh, Christ! - / How smells from a wave, / And slimy creatures crawl / From the viscous depth. / At night a round dance is made by / Wandering fires. / Like a witch's candles, they are green, / They are red, white. / And many dreamed a terrible spirit, / For us it is more terrible than plague, / Swam after us under the water / From the countries of snow and darkness. / In the throat of each of us / The tongue was dried up, / We were silent as if all / Filled our mouths with soot" [5, p. $442-444]$. In Gumilev's translation the tub, lying upside down, is mentioned instead of withered boards; phrases "How smells of rot - oh, Christ!" and "How smells from a wave" again do not transfer a disgusting picture of rotting water; "a witch's oils" is translated as "a witch's candles"; instead of blue colour of fires red is mentioned; the depth, at which there was a spirit, is not specified.

\section{DISCUSSION}

The trembling worship for mysticism of life, morality lesson taught for the mankind by Fair God, unexpected subject differences, psychologism characteristic for Russian literature of the second half of the XIXth century in many respects caused the appearance of F.B.Miller's, N.L.Pushkarev's and A.A.Korinfsky's translations. The developed subjects and characters like the image of the Ancient Mariner were not something alien in Russia, moreover, were integrally acquired by Russian literature owing to the harmony of the issue, touched by the English poet, for Russian classics. F.M.Dostoyevsky's thought, that "the person deserves happiness and always by suffering", reflects the idea of Coleridge's poem according to which the Ancient Mariner could return to real life, having only found an ability "to feel compassion for the neighbour".

At the same time the English original was significantly changed in F.B.Miller, N.L.Pushkarev and A.A.Korinfsky's interpretations. For example, in F.B.Miller's translation there are deviations in the image of the bride in the wedding scene, the episode, where the perception of the ship by the monk-hermit is described, is very laconically presented. Despite preserving the quantity of lines close to the original and sequence in translation of terms, which gave a certain sea colour to the language of Coleridge's poem, Miller changed the structure of the original, having moved the beginning of the dialogue of spirits from the fifth part to the sixth one.

In N.L.Pushkarev's translation a special attention is paid to the image of the Ancient Mariner, and the fact that he had magnetic, fiery eyes is repeatedly repeated many times. Also a distinctive feature of his translation is its abundance with comparisons. In Pushkarev's translation there are more lines than in the original, what, in many respects, is caused by adherence to principles of preservation of the English original repetitions by the Russian translator.

In A.A.Korinfsky's translation descriptions of the Ancient Mariner and his team's sufferings underwent considerable changes. The translator turned the ballad description into Gothic one by means of the prevailing use of the corresponding lexicon. In Korinfsky's interpretation, as, however, in Pushkarev's one, the Ancient Mariner gradually becomes a more and more "dark", negative character. While describing a thunderstorm in chapter 5, Korinfsky surpassed the original in beauty. Korinfsky's interpretation of condemnation of the Ancient Mariner for the murder of the albatross is not absolutely right. At the same time only Korinfsky, the only of Russian translators of the poem, succeeded in correct interpretation of the lines, which bear the most significant and deepest thought designed to show how supernatural life intertwines with real one: "There is a mystery of movement / In a rest picture, / In an eternal picture... / Mysterious force / Is disturbed by nothing..." [8, p. 11]. As a result of such transformations the semantic and figurative structure of the original was broken, and Korinfsky did not strive to preserve the quantity of lines and poetic metre.

Miller, and Pushkarev, and Korinfsky characterize the albatross as a good omen, though Coleridge does not give any estimates to this bird in his verses. The scene of the sea rotting, presented in their translations, does not transfer the whole detestation of this process described in the original, though Korinfsky considerably embellished this fragment. Realizing the importance of the description of the ghost ship, Russian translators 
of the second half of the XIXth century offered the interpretations significantly different not only from each other, but also from the English original. The image of "Life-in-Death", accurately found by the English poet and ideologically significant for the expression of the hero's internal state, underwent essential changes. The episode, when the Ancient Mariner blesses beings, which seemed disgusting slugs earlier, is not so bright and expressive in Miller, Pushkarev and Korinfsky's interpretations. Miller did not translate the lines, showing loneliness of the Ancient Mariner ("...this soul hath been / Alone on a wide wide sea: / So lonely 'twas, that God himself / Scarce seemed there to be" [5, p. 106]). Subsequently they were successfully translated by N.S.Gumilev: "... I was in the seas / Desert lonely, / As lonely as, maybe, / There is only God" [5, p. 465]. Pushkarev and Korinfsky superfluously expanded the semantic plan of these lines.

\section{CONCLUSIONS}

According to art expressiveness, Russian translations of Coleridge's poem made in the second half of the XIXth century are worse than the English original. Obviously, it was very difficult to translate Coleridge with preserving the contents and form as it was almost impossible to keep, without changing contents, music of verses with double rhymes.

The versatility and symbolical character, which were in the plot and figurative system of the poem, promoted the interpretation of the "Ancient Mariner" as historical and philosophical searches characteristic for the Russian historical and cultural process of the Silver Age, and the emergence in 1919 of the translation made by N.S.Gumilev. "The Rime of the Ancient Mariner" had something in common with Gothic interests of the Russian poet, reflected his addiction to a ballad genre. Some N.S.Gumilev's original works in many respects anticipated his address to the translation of S.-T.Coleridge's poem. So, in the poem "Fra Beato Angelico" the Ancient Mariner's sermon is almost literally formulated: "But everything in himself contains the person, / Who loves the world and believes in God", and the lyrical ballad "Appointment" is close to the poem by Coleridge in images and metre - a combination of four and three metre iambus. It is interesting that the particular poetic interest of Coleridge in the Sun and the Moon as equal art dominants of the universe naturally entered the Russian literary context only at the beginning of the XXth century. Earlier the hymn address only to the Sun had been characteristic for the Russian literary tradition, what affected translations of the second half of the XIXth century, in which the aspiration "to transfer" good functions of the Moon to the Sun is notable. The Silver Age approved the equal relation to both stars. N.S.Gumilev's translation of "The Rime of the Ancient Mariner" is almost faultless - the Russian poet precisely adhered to the "nine precepts of the translator" established by him, observing the number of verses, and metre, and rhymes, and character of the vocabulary, and sense of the original; besides, N.S.Gumilev kept all S.-T.Coleridge's repetitions to give the importance and dramatic nature to the narration.

Thus, the comparative analysis of the English original and Russian translations made by F.B.Miller, N.L.Pushkarev, A.A.Korinfsky and N.S.Gumilev helped to find the originality of reception of the poem in the second half of the XIXth century and at the beginning of the XXth century.

\section{ACKNOWLEDGEMENTS}

The article is made within the project \#17-18-01006 "The Evolution of the Russian Poetic Translation (the XIXth - the beginning of the XXth centuries)" of the Russian Science Foundation.

\section{REFERENCES}

1. Coleridge S.-T. Biographia Literaria. Chapter XIV https://www.saylor.org/site/wpcontent/uploads/2011/02/Biographia-Litararia-Coleridge.pdf

2. Myers F.W.H. Wordsworth. Part 2 http://lightnovelgate.com/chapter/wordsworth/chapter_2

3. Edwards Ph. The Story of the Voyage: Sea-Narratives in Eighteenth-Century England. - Cambridge: Cambridge University Press, 1994. - Part II. A Disconsolate Black Albatross. - 246 p.

4. Zherlitsyn M. Coleridge and English Romanticism. - Odessa: Economic Printing House, 1914. - [4], XV, II, [2], $300 \mathrm{p}$.

5. Coleridge S.-T. Poems / A Preface and Comments by A.N.Gorbunov. - Moscow: Raduga, 2004. - 512 p.

6. The English Poets in Biographies and Samples / Comp. by N.V.Gerbel. - St. Petersburg: A.M.Kotomin's Printing House, 1875. - 448 .

7. Coleridge S.-T. The Song of the Ancient Mariner/Tr. by N.L.Pushkarev / Svet I Teni. - 1878. -\#2. - P. 11 -13; \#3. - P. 19-20; \#4. - P. 27 - 28; \#5. - P. 35 - 36; \#6. - P. 43 - 44; \#7. - P. 51 - 52. 
8. Coleridge S.-T. The Old Seaman / Tr. and a Preface by Apollon Korinfsky. - The 2nd edition. - KievKharkov: F.A.Ioganson, 1897. - 27, [2] p.

9. Lowes J.L. The Road of Xanadu. A Study in the Ways of the Imagination. - New York: Vintage Books, 1959. - XII, 574 p.

10. Mackail J.W. Coleridge's Literary Criticism. - New York: Frederick Ungar Publishing Company, 1984. $-298 p$.

11. Knight G.W. The Starlit Dome: Studies in the Poetry of Vision. - London: Oxford University Press, 1971. $-330 \mathrm{p}$.

12. Coleridge S.-T. Collected Letters: In 6 v. / Ed. By E.L.Griggs. - London: Clarendon Press, 1956. - V. 1. $-696 p$. 